М.В. Науменко

Харківський національний університет Повітряних Сил ім. І. Кожедуба, Харків

\title{
УДОСКОНАЛЕНА МАТЕМАТИЧНА МОДЕЛЬ ВАРТОСТІ БАГАТОЦІЛЬОВИХ ТАКТИЧНИХ ВИНИЩУВАЧІВ
}

Представлено удосконалену математичну модель вартості багатоиільових тактичних винищувачів, яка на відміну від існуючої, побудована на вибіриі, щзо включає інформацію про найсучасніші типи багаточільових тактичних винищувачів, реалізованих в світовій практиці військового авіабудування, та більш адекватно відображає залежність ичіни серійних виробів на світовому ринку озброєнь від узагальнених показників їх якості. Показниками якості у факторному просторі математичної моделі прийняті коефіцієнти бойових потенціалів багатоцільових тактичних літаків при виконанні ними завдань знищення противника у повітрі та завдань ураження наземних иілей, визначених у еталоні більш сучасного багаточільового винищувача типу F-16E. Побудована математична модель для виключення впливу факторів інфляції дозволяє визначити ціну на придбання серійних літаків на світовому ринку озброєнь за курсом долару США 2014 фінансового року.

Ключові слова: планування на основі спроможностей, критерії раціональності, науково-методичний апарат, оптимізація, раціональна програма розвитку, система озброєння тактичної авіації Повітряних Сил Збройних Сил Украӥни.

\section{Вступ}

Постановка проблеми. Одним з основних напрямків реформування сектору безпеки і оборони України є перехід на оборонне планування на основі спроможностей [1-4]. Важливою складовою у розв'язуванні проблем оборонного планування, особливо при обгрунтуванні та формуванні довгострокових програм і планів розвитку озброєння та воєнної техніки (ОВТ), в тому числі, при розгляді та аналізі альтернативних шляхів вирішення проблемних питань процесу реалізації озброєння (переозброєння) військових формувань сектору безпеки і оборони є оцінювання вартості зразків ОВТ на світовому ринку озброєнь [2-12]. Отримання кількісних оцінок такого роду має стати відправною межею для аналізу доцільності розгляду різних типів зразків ОВТ у якості альтернатив для їх закупівлі з метою набуття необхідних бойових спроможностей збройними формуваннями. Також оцінювання вартості серійних зразків ОВТ, які можуть розглядатися як альтернативні для закупівлі, має стати підгрунтям для формування запиту та планування видатків Державного бюджету у середньо- та довгостроковій перспективі, що мають бути спрямовані до Сектору безпеки та оборони, та які будуть обумовлювати фінансову складову системи обмежень формалізованих критеріїв при синтезі раціональних програм розвитку системи ОВТ, зокрема системи ОВТ тактичної авіації Повітряних Сил Збройних Сил України [13-14].

В залежності від варіативності нестачі бойових спроможностей тактичної авіації Повітряних Сил Збройних Сил України на початку довгострокового періоду планування розвитку іiі системи озброєння необхідно розглядати можливі варіанти стратегій переоснащення авіаційних частин на нову бойову авіаційну техніку закордонного виробництва для ліквідації наявної нестачі спроможностей [13-16]. Обгрунтованість такого підходу підкріплено Візією Повітряних Сил 2035, представленою у 2020 році, де пріоритетом розвитку авіації Повітряних Сил (ПС) Збройних Сил (3С) України визначено переоснащення тактичної авіації на нові багатоцільові винищувачі [17].

В залежності від обраної стратегії розвитку системи ОВТ тактичної авіації ПС ЗС України при формуванні програми розвитку доцільно використовувати адаптовані для окремого варіанту стратегії формалізовані критерії оцінюванні програм розвитку системи ОВТ авіації, які розроблюються. Незалежно від обраних стратегії розвитку системи ОВТ авіації та критеріїв оцінювання відповідних програм розвитку, однією із значущих складових запропонованих критеріїв є оцінювання фінансової складової, і у першу чергу - вартісних характеристик багатоцільових тактичних винищувачів на світовому ринку озброєнь [13-16].

Вартісні показники багатоцільових винищувачів, сумісно із темпами їх виробництва, значною мірою обумовлюються тенденціями розвитку світового ринку озброєнь, що у свою чергу, висуває для потенційних покупців бойової авіаційної техніки певні обмеження щодо можливостей iї закупівлі 
[18]. Тому для формування програм та планів розвитку системи ОВТ тактичної авіації ПС ЗС України, які можуть бути реалізованими із урахуванням сукупності системних факторів, необхідно мати можливість отримувати попередні оцінки вартості серійних зразків перспективних типів багатоцільових тактичних винищувачів на світовому ринку озброєнь. Для розв'язування зазначеної прикладної задачі необхідно мати відповідну методику оцінювання, що базується на використанні адекватної моделі вартості сучасної бойової авіаційної техніки [19].

Аналіз останніх досліджень і публікацій. Дослідженню проблем раціонального використання видатків Державного бюджету України на забезпечення потреб Сектору безпеки і оборони, зокрема, Збройних Сил України, управління розподілом фінансових ресурсів, удосконаленням нормативноправових документів 3 оборонного планування і фінансового забезпечення потреб оборони і безпеки України вітчизняними вченими приділено достатньо уваги [20-24].

Але, разом 3 тим, залишається відкритим питання щодо сучасного методичного забезпечення оцінювання (прогнозування) вартісних показників зразків ОВТ, зокрема, бойової авіаційної техніки, в залежності від їх узагальнених показників якості. Наявні на сьогоднішній час математичні моделі залежності вартості бойових літаків, які серійно виробляються (вироблялися), що грунтуються на встановленні формалізованої залежності вартості багатоцільових тактичних винищувачів від коефіцієнтів їх бойових потенціалів за об'єктивних причин, пов'язаних із неминучим розвитком складності технологій їх виробництва, адекватно не відображають сучасні тенденції розвитку бойової авіаційної техніки [25]. Також слід відзначити, що такі моделі були розроблені для тактичних винищувачів, які розроблялися та вироблялися країнами для задоволення потреб у оснащенні бойовою авіаційною технікою власних збройних угруповань. Актуальність удосконалення математичних моделей вартості бойової авіаційної техніки обумовлюється, по-перше, необхідністю адекватного прогнозування тенденцій розвитку цього сегменту світового ринку озброєнь, а по-друге, необхідністю прогнозування можливих темпів оновлення новітнім озброєнням повітряної компоненти потенційного противника на підставі системного аналізу вартісних показників зразків OBТ та обсягів фінансування, що плануються вірогідним противником спрямовувати на переозброєння своїх збройних сил у середньо- та довгостроковій перспективі.

Відповідно до цього, метою статті $є$ розробка удосконаленої математичної моделі, представленої у вигляді формалізованої залежності вартості серійного зразка багатоцільового тактичного винищувача від ступеня його бойових властивостей при виконанні завдань знищення противника у повітрі та завдань ураження наземних цілей.

\section{Виклад основного матеріалу}

На сьогодні найсучаснішою математичною моделлю вартості серійних багатоцільових літаків тактичної авіації, яка грунтується на визначеній формалізованій залежності вартості серійного бойового літака від ступеня бойових властивостей літаків тактичної авіації при виконанні завдань знищення противника у повітрі та завдань ураження наземних цілей, є наступна залежність [25]:

$$
\begin{gathered}
C_{1}=10,545+0,12 \cdot K_{\text {бппов }}+0,488 \cdot K_{\text {бпназ }}+ \\
+0,015 \cdot K_{\text {бппов }} \cdot K_{\text {бпназ }},
\end{gathered}
$$

де $C_{1}$ - вартість серійного багатоцільового тактичного винищувача, \$ млн. в цінах 1997 фінансового року;

$K_{\text {бппов }}$ - коефіцієнт бойового потенціалу багатоцільового тактичного винищувача у виконанні ним винищувальних задач (за еталон прийнятий F-4B);

$K_{\text {бпназ }}-$ коефіцієнт бойового потенціалу багатоцільового тактичного винищувача у виконанні ним ударних задач (за еталон прийнятий F-4B).

Аналіз використання зазначеної моделі для оцінювання вартості сучасної бойової авіаційної техніки свідчить про значний рівень невідповідності розрахованих за цією моделлю вартостей серійних зразків бойової авіаційної техніки та реальних показників ціни серійних виробів багатоцільових тактичних літаків на сучасному світовому ринку озбро$\epsilon н ь$, навіть після застосування відомих процедур приведення розрахованих за моделлю (1) цін за допомогою відомих коефіцієнтів - дефляторів.

Слід зазначити, що при розробці математичної моделі (1) було встановлено, що просте приведення вартості літаків до цін одного року для коректного ïx порівняння не відображує вплив розвитку технологій авіабудування на динаміку вартості літака, внаслідок чого зразки бойової авіаційної техніки із значно нижчими бойовими властивостями мають показники вартості не менш, ніж сучасні бойові літаки [25]. Крім того, іноді приведена до одного року ціна літаків застарілих типів може бути вищою за вартість не тільки сучасних, а й перспективних зразків. Це показало неможливість безпосереднього використання наявного статистичного матеріалу щодо вартостей бойової авіаційної техніки для побудови математичних моделей вартості серійного бойового літака методами математичної статистики.

В табл. 1 наведені результати оцінювання відповідності прогнозних показників вартості серійних 
багатоцільових тактичних винищувачів. Вартості багатоцільових тактичних винищувачів були визна- чені на основі огляду доступних джерел інформації [26-40].

Таблиця 1

Результати оцінювання відповідності прогнозних показників вартості сучасних та перспективних бойових тактичних літаків за моделлю (2) реальним показникам їх вартості на сучасному світовому ринку озброєння

\begin{tabular}{|c|c|c|c|c|c|}
\hline \multirow[t]{2}{*}{ Тип літака } & \multirow[t]{2}{*}{$\begin{array}{c}\text { Кбп вин } \\
(\mathrm{F}-16 \mathrm{E})\end{array}$} & \multirow[t]{2}{*}{$\begin{array}{c}\text { Кбп удар } \\
(\mathrm{F}-16 \mathrm{E})\end{array}$} & $\begin{array}{c}\text { Вартість тактичних } \\
\text { літаків }\end{array}$ & $\begin{array}{c}\text { Розрахункова вартість } \\
\text { тактичних літаків } \\
\text { за моделлю (2) }\end{array}$ & \multirow[t]{2}{*}{$\begin{array}{l}\text { Відносна } \\
\text { похибка } \\
(\%)\end{array}$} \\
\hline & & & \multicolumn{2}{|c|}{ (\$ млн. у цінах 2014 фінансового року) } & \\
\hline $\mathrm{F}-15 \mathrm{C}$ & 1,000 & 0,738 & 41,65 & 31,67 & 23,96 \\
\hline F-16A & 0,695 & 0,162 & 21,39 & 19,43 & 9,12 \\
\hline $\mathrm{F}-16 \mathrm{C} / \mathrm{D}$ & 0,695 & 0,738 & 69,01 & 29,26 & 57,60 \\
\hline JAS-39A & 1,084 & 0,809 & 68,00 & 33,75 & 50,36 \\
\hline F-15E & 1,217 & 1,324 & 100,00 & 45,65 & 54,35 \\
\hline $\mathrm{F}-16 \mathrm{E}$ & 1,000 & 1,000 & 56,00 & 36,74 & 34,39 \\
\hline $\begin{array}{c}\text { Dassault } \\
\text { Mirage } 2000\end{array}$ & 0,955 & 1,417 & 46,68 & 44,23 & 5,27 \\
\hline Миг-29 & 0,985 & 0,467 & 31,35 & 26,35 & 15,96 \\
\hline $\mathrm{Cy}-27 \mathrm{C}$ & 1,236 & 0,500 & 88,58 & 28,52 & 67,80 \\
\hline$C y-30 M K$ & 1,061 & 0,973 & 75,00 & 36,81 & 50,91 \\
\hline Су-35 & 1,412 & 1,112 & 109,20 & 43,30 & 60,35 \\
\hline F-35 A & 1,246 & 1,619 & 93,30 & 52,25 & 43,99 \\
\hline Rafale & 1,067 & 1,087 & 85,00 & 39,12 & 53,98 \\
\hline EF-2000 & 1,182 & 1,044 & 123,00 & 39,45 & 67,93 \\
\hline JAS-39C/D & 0,842 & 0,829 & 65,00 & 32,07 & 50,65 \\
\hline JAS-39E/F & 1,040 & 0,933 & 76,90 & 35,82 & 53,43 \\
\hline
\end{tabular}

Джерело: розроблено автором.

Для коректності розрахунків прогнозних значень вартості серійних бойових літаків, модель (1) була скоректована для проведення розрахунків коефіцієнтів бойових потенціалів від зразка-еталона F-4B до більш сучасного багатоцільового винищувача F-16Е, внаслідок чого вона набула вигляду:

$$
\begin{aligned}
C_{1}=15 & +2,4 \cdot K_{\text {бппов }}+11,9072 \cdot K_{\text {бпназ }}+ \\
& +7,4298 \cdot K_{\text {бппов }} \cdot K_{\text {бпназ }},
\end{aligned}
$$

де $K_{\text {бппов }}, K_{\text {бпназ }}$ - коефіцієнти бойового потенціалу багатоцільового тактичного винищувача у виконанні ним винищувальних задач та ударних задач, виміряні в єдиному еталоні - сучасному літаку F-16Е, відповідно.

Вартості всіх літаків, що увійшли до табл. 1, було приведено до цін 2014 фінансового року з використанням дефлятору [42].

Аналіз даних табл. 1 свідчить, що відносні відхилення фактичних вартостей тактичних винищувачів, які серійно вироблялися (виробляються), від прогнозних вартостей, що розраховані за відомою математичною моделлю, є неприпустимо великими. Це свідчіть про необхідність удосконалення існую- чої математичної моделі вартості серійного бойового літака від показників ступеня його бойових властивостей при виконанні завдань знищення противника у повітрі та завдань ураження наземних цілей.

3 метою виявлення тенденцій впливу коефіцієнтів бойового потенціалу багатоцільових тактичних

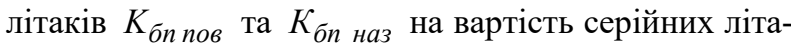
ків тактичної авіації та для визначення можливих варіантів вигляду форм математичних моделей (які можуть розглядатися в якості альтернативних форм), було побудовано проекції точок, що відповідають наявним реалізаціям на площини системи координат факторного простору $\left\{K_{\text {бп пов }}, K_{\text {бп наз }}\right\}$. В результаті аналізу отриманих даних було висунуто гіпотезу, що в якості альтернативних варіантів функціональних залежностей вартості серійного літака від його коефіцієнтів бойового потенціалу можуть розглядатися логарифмічна, степенева та експоненціальна функції (рис. 1-2).

Таким чином, первинні формалізовані вигляди альтернативних апроксимуючих функцій були обраними наступними: 


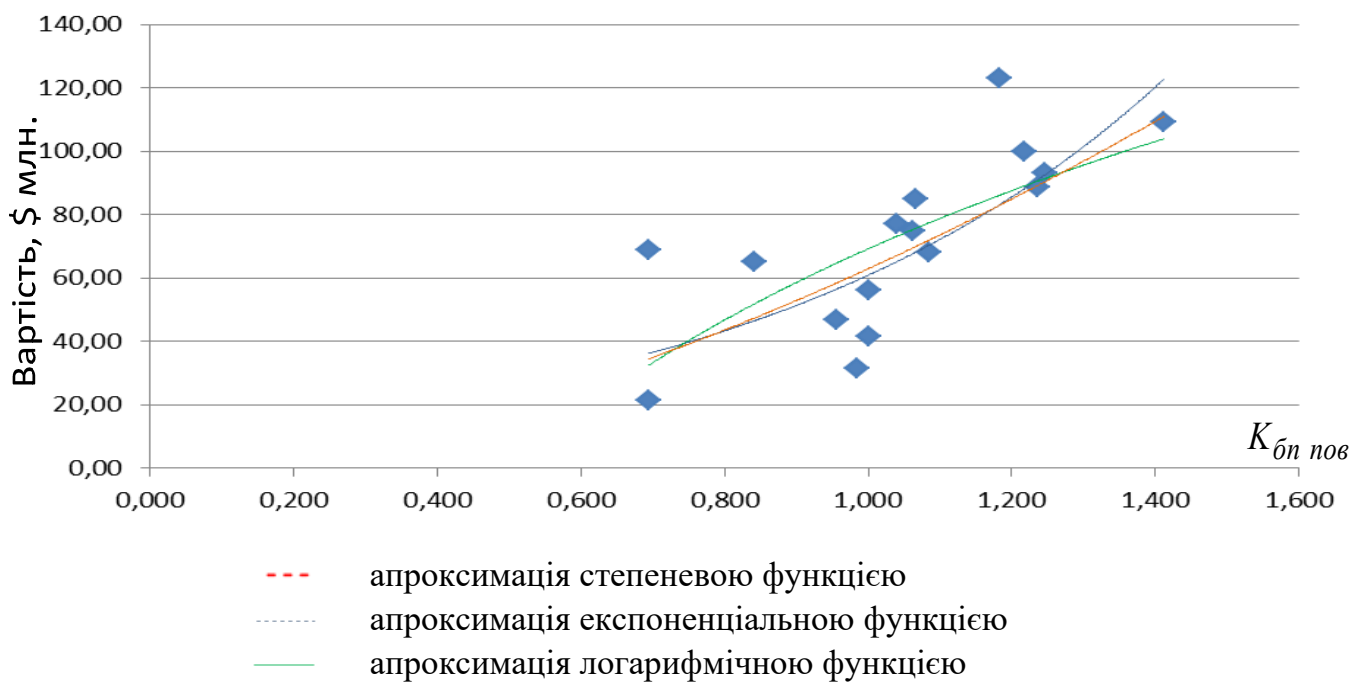

Рис. 1. Проекція залежності вартості серійного літака від $K_{\text {бп пов }}$

Джерело: розроблено автором.

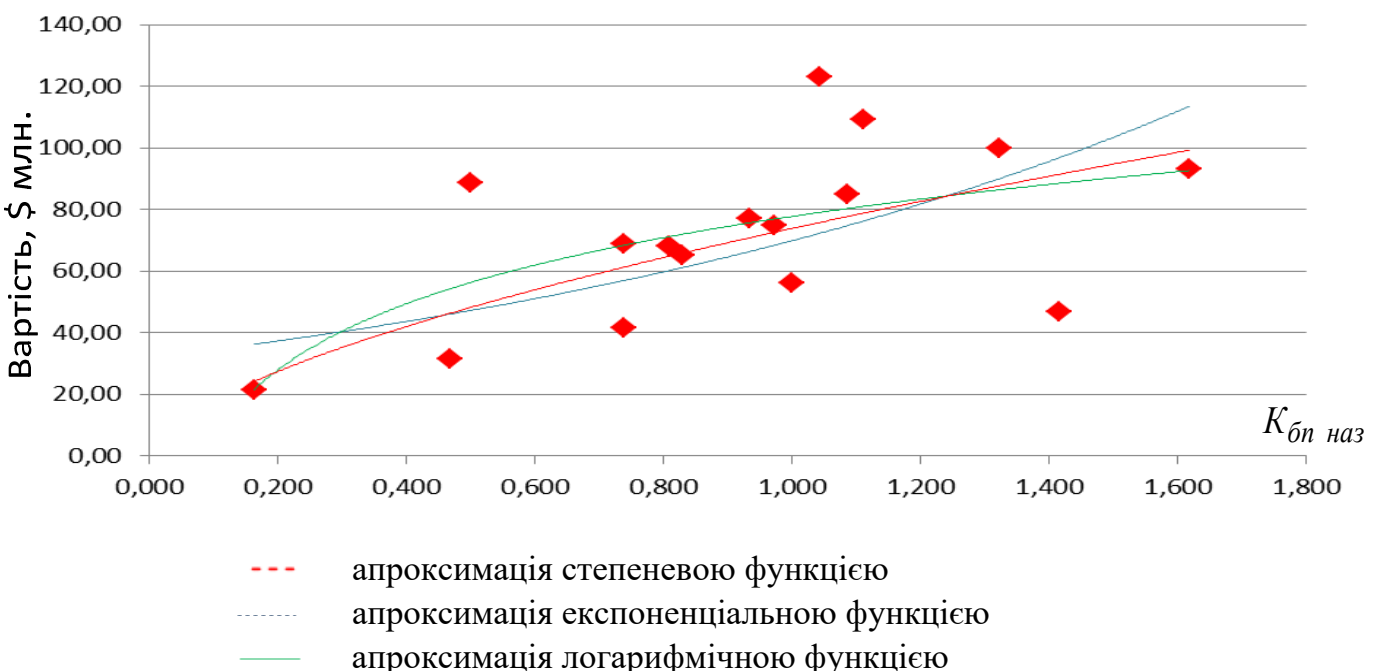

Рис. 2. Проекція залежності вартості серійного літака від $K_{\text {бn наз }}$

Джерело: розроблено автором.

$$
\begin{gathered}
C_{1}=a_{0}+a_{1} \cdot \ln \left(K_{\text {бппов }}\right)+a_{2} \cdot \ln \left(K_{\text {бпназ }}\right) \\
C_{1}=a_{0}+a_{1} \cdot e^{K_{\text {бпов }}}+a_{2} \cdot e^{K_{\text {бпназ }}}+a_{3} \cdot e^{K_{\text {бпназ }}} \cdot e^{K_{\text {бппов }}} \\
C_{1}=a_{0}+\left(K_{\text {бппов }}\right)^{a_{1}}+\left(K_{\text {бпназ }}\right)^{a_{2}}+\left(K_{\text {бппов }} \cdot K_{\text {бпназ }}\right)^{a_{3}} .
\end{gathered}
$$

де $a_{0}, a_{1}, a_{2}$ - коефіцієнти математичних моделей, що підлягають визначенню.

Для кожної з визначених альтернативних форм залежності вартості серійних літаків тактичної авіації шляхом складання системи нормальних рівнянь, із застосуванням відомої та добре апробованої на практиці процедури апроксимації за методом найменших квадратів, були визначені значення невідомих коефіцієнтів при відповідних факторах, та для кожної із альтернативних форм функціональної залежності вартості серійного тактичного літака було проведено оцінювання її адекватності та точності.

Для визначення кращої для апроксимації вибірки та оцінювання придатності до практичного застосування альтернативних варіантів математичної моделі вартості серійного тактичного літака було визначено наступну систему відомих та таких, що поширено застосовуються для вирішення такого роду задач, зовнішніх критеріїв [18; 25; 42-47], а саме:

- середньоквадратичну помилку на інтервалі інтерполяції, при використанні в якості $C_{1 j}^{\text {реал }}$ зна- 
чень вартості серійного літака зі складу контрольної вибірки статистичного матеріалу ємністю $L$, а в якості $C_{1 j}^{\text {розр }}$ - розраховане значення по моделі:

$$
\sigma_{\varepsilon}{ }^{2}=D=\sum_{j=1}^{L} \frac{\left(C_{1 j}^{\text {реал }}-C_{1 j}^{\text {розр }}\right)^{2}}{L(L-1)} ;
$$

- абсолютне середнє відхилення в області інтерполяції:

$$
E=(D)^{0,5}
$$

- середню вірогідну похибку в області інтерполяції:

$$
r_{A}= \pm 0,6745 E ;
$$

- максимальну відносну помилку розрахунків в області інтерполяції:

$$
\delta_{\max }=\max _{j=1 . . L} \frac{\left|C_{1 j}^{\text {реал }}-C_{1 j}^{\text {розр }}\right|}{\bar{C}_{1 j}^{\text {реал }}} ;
$$

- середню помилку апроксимації:

$$
\bar{A}=\frac{1}{L} \sum_{j=1}^{L}\left|\frac{C_{1 j}^{\text {реал }}-C_{1 j}^{\text {розр }}}{C_{1 j}^{\text {реал }}}\right| \cdot 100 \% ;
$$

- середнє відносне відхилення:

$$
\bar{\delta}=\sum_{j=1}^{L} \frac{C_{1 j}^{\text {реал }}-C_{1 j}^{\text {розр }}}{L} .
$$

Значення показників зовнішніх критеріїв визначалися на базі змішаної контрольної вибірки, застосування якої для оцінювання якості апроксимації було обумовлено пасивним характером спостережень за реалізаціями літаків на світовому рівні, а також суттєвою обмеженістю обсягу наявних реалізацій. Саме пасивний характер спостережень не дозволяє застосовувати відомі комплексні критерії для перевірки узгодженості моделей [18; 25]. Результати порівняльного оцінювання якості отриманих альтернативних форм математичної моделі наведено у табл. 2.

Таблиця 2

Результати порівняльного оцінювання альтернативних математичних моделей на контрольній вибірці

\begin{tabular}{|c|c|c|c|c|c|c|}
\hline Альтернативні варіанти моделі & $D$ & $E$ & $r_{A}$ & $\delta_{\max }$ & $\bar{\delta}$ & $\bar{A}$ \\
\hline$C_{1}=58,89+\left(K_{\text {бппов }}\right)^{9,01}+\left(K_{\text {бпназ }}\right)^{2,27}+\left(K_{\text {бппов }} \cdot K_{\text {бпназ }}\right)^{4,73}$ & 26,09 & 16,34 & 11,02 & 1.12 & 28,07 & 25,28 \\
\hline$C_{1}=-27,45+24,55 \cdot e^{K_{\text {бпов }}}+14,63 \cdot e^{K_{\text {бпназ }}}-1,6 \cdot e^{K_{\text {бпназ }}} \cdot e^{K_{\text {бппов }}}$ & 49,39 & 7,03 & 4,74 & 0,47 & 14,38 & 15,62 \\
\hline$C_{1}=73,2+76,38 \cdot \ln \left(K_{\text {бппов }}\right)+15,28 \cdot \ln \left(K_{\text {бпназ }}\right)$ & 38,81 & 6,23 & 4,20 & 0,39 & 12.2 & 13,16 \\
\hline
\end{tabular}

Джерело: розроблено автором.

Серед альтернативних форм функціональної залежності вартості серійного літака від узагальнених показників його якості, після оцінювання за представленою системою зовнішніх критеріїв (6) (11), серед яких найбільш показовим є середня помилка апроксимації (10), доцільно обрати логарифмічну залежність, оскільки допустимою границею середньої помилки апроксимації є значення не більше 15\% [44-47].

$$
\begin{gathered}
C_{1}=73,2+76,38 \cdot \ln \left(K_{\text {бппов }}\right)+ \\
+15,28 \cdot \ln \left(K_{\text {бпназ }}\right) \pm 4,2 .
\end{gathered}
$$

Крім того, важливим критерієм при виборі моделі є вірність описання нею відомих тенденцій зміни вартості серійного тактичного літака при зміні значень показників його коефіцієнтів бойового потенціалу при виконанні завдань знищення противника у повітрі та завдань ураження наземних цілей. Якщо відомо, що показник (в даному випадку вартість серійного літака) при збільшення якогось часткового показника має також зростати, що цілком логічно та не протирічить відомим тенденція розвитку бойової авіаційної техніки, відповідна часткова похідна повинна бути позитивною в області інтерполяції. Перевірка варіанту функціональної залежності, яка може стати остаточним вибором у якості математичної залежності вартості серійного тактичного літака від значень його коефіцієнтів бойового потенціалу, показала, що часткові похідні логарифмічної згортки (12) є позитивними в межах фізичних значень незалежних змінних зі складу моделі. Тобто знаки значень всіх часткових похідних залежності (12) вірно відображають тенденцію зміни показника вартості серійного тактичного літака при зміні кожного фактору, які враховані у моделі. При збільшенні значень часткових показників бойових потенціалів літака спостерігається збільшення його вартості на світовому ринку озброєнь, що співпадає з попередньою оцінкою відомих з практики тенденцій зміни вартості при підвищенні показників бойових властивостей літаків (рис. 1-2).

Таким чином, вибір з альтернативних варіантів форм функціональної залежності вартості серійного тактичного літака від показників його бойових властивостей на користь (12) грунтується на результатах оцінювання точності математичної моделі та ре- 
зультатах оцінювання адекватного відображення відомих тенденцій зміни вартості літака при зміні показників його якості. 3 метою остаточної перевірки працездатності побудованої моделі (12) було сформовано контрольну вибірку. Відповідні дані щодо оцінювання значень відносної похибки розрахунків за допомогою математичної моделі (12) на контрольній виборці наведено у табл. 3.

Таблиця 3

Контрольна вибірка літаків тактичної авіації

\begin{tabular}{|c|c|c|c|c|c|}
\hline \multirow[t]{2}{*}{ Тип літака } & \multirow[t]{2}{*}{$\begin{array}{c}K_{\text {бппов }} \\
\text { (еталон } \\
\text { F-16Е) }\end{array}$} & \multirow[t]{2}{*}{$\begin{array}{c}K_{\text {блназ }} \\
\text { (еталон } \\
\text { F-16Е) }\end{array}$} & $\begin{array}{c}\text { Анонсована вартість } \\
\text { тактичних літаків }\end{array}$ & $\begin{array}{c}\text { Розрахована } \\
\text { за математичною } \\
\text { моделлю (12) вартість } \\
\text { тактичних літаків }\end{array}$ & \multirow[t]{2}{*}{$\begin{array}{c}\text { Відносна } \\
\text { похибка }\end{array}$} \\
\hline & & & \multicolumn{2}{|c|}{ (\$ млн. у цінах 2014 фінансового року) } & \\
\hline Cy-35 & 1,412 & 1,112 & 109,20 & 101,18 & 0,07 \\
\hline МиГ-35 & 1,260 & 1,070 & 67,99 & 91,86 & $-0,35$ \\
\hline Cy-57 & 1,667 & 1,479 & 128,47 & 118,20 & 0,08 \\
\hline F-35 A & 1,246 & 1,619 & 93,30 & 97,36 & $-0,04$ \\
\hline Rafale & 1,067 & 1,087 & 85,00 & 79,41 & 0,07 \\
\hline EF-2000 & 1,182 & 1,044 & 123,00 & 86,65 & 0,30 \\
\hline JAS-39C/D & 0,842 & 0,829 & 65,00 & 57,16 & 0,12 \\
\hline JAS-39E/F & 1,040 & 0,933 & 76,90 & 75,13 & 0,02 \\
\hline
\end{tabular}

Джерело: розроблено автором.

3 наведених даних видно, що максимальна відносна похибка розрахунків за розробленою моделлю дорівнює $30 \%$ - у бік завищення розрахункових даних, та $35 \%$ - у бік заниження. Середня квадратична похибка на контрольній вибірці складає 38,8, а вірогідна похибка $\pm 4,2$. Отриманні оцінки свідчать про задовільне описання моделлю залежності вартості серійних тактичних винищувачів від їх коефіцієнтів бойового потенціалу.

Найбільші відхилення розрахункових показників вартості по моделі (12) від анонсованої вартості серійних багатоцільових літаків на світовому ринку озброєнь припадають на перспективний тактичний літак виробництва РФ МиГ-35 та літак виробництва європейського консорціуму Eurojet Turbo $\mathrm{GmbH}$ EF-2000. Можна зробити припущення, що це $\epsilon$ наслідком відмінностей у структурі ціни, яка встановлюється виробником серійних бойових машин в РФ та $\mathrm{CC}$, які обумовлені особливостями чинного законодавства в даних країнах, що врегульовують процеси ціноутворення та питому вагу складової, яка спрямована на забезпечення соціальних гарантій персоналу, задіяного у виробництві. Так, наприклад, у країнах Свропи середня оплата праці у авіабудівній галузі складає навколо \$ 4800-4900 на місяць, i цей показник в рази перевищує відповідні показники в РФ. Це призводить, з одного боку, до можливості використання у ціновій політиці РФ демпінгування цін на світовому ринку озброєнь, а 3 другого боку, вимушеному у ціновій політиці європейського виробника завищенню цін на відповідну продукцію, тобто неможливістю експорту продукції за цінами, більш відповідними якості товару [48-51].
В цілому, результати перевірки свідчать про задовільну точність описання апроксимуючою залежністю (12) даних контрольної вибірки та вірну поведінку зміни показника вартості серійного тактичного літака від обраних факторів, а побудована математична модель може бути рекомендованою для практичного використання в ході проведення обгрунтування програм і планів розвитку системи ОВТ тактичної авіації ПС ЗС України.

\section{Висновки}

Побудовано математичну модель вартості багатоцільових літаків тактичної авіації, які серійно виробляються. Дана модель, на відміну від існуючої, більш адекватно відображає залежність ціни сучасних та перспективних багатоцільових винищувачів на світовому ринку озброєнь від узагальнених показників їх якості. За результатами перевірки працездатності розробленої математичної моделі та оцінювання характеристик точності описання залежності вартості серійних літаків тактичної авіації від показників їх бойових властивостей, можна зробити висновок про іiї придатність до практичного застосування в ході обгрунтування напрямів розвитку системи озброєння авіації Повітряних Сил Збройних Сил України на довгостроковій перспективі. Подальші дослідження планується спрямувати на розробку методики оцінювання багатоцільових літаків тактичної авіації, які можуть розглядатися як альтернативні для закупівлі на світовому ринку озброєнь 3 метою оснащення ними тактичної авіації ПС ЗС України. 


\section{Список літератури}

1. Оборонна реформа: системний підхід до оборонного менеджменту: монографія / А. Павліковський, В. Фролов, Ф. Саганюк та ін.; за заг. ред. А. Сиротенка. - К.: НУОУ, 2020. - 274 с.

2. Оборонний огляд: український вимір 2014-2018: монографія / Ф. Саганюк, А. Павліковський, П. Щипанський та ін.; за заг. ред. І. Руснака. - К.: МО та ГШ ЗС України, НУОУ, 2019. - 196 с.

3. Сектор безпеки і оборони України: стратегічне керівництво та військове управління: монографія / Ф.В. Саганюк, В.С. Фролов, В.І. Павленко та ін.; за ред. д. військ. н., проф. І.С. Руснака. - К.: ЦЗ МО та ГШ ЗС України, 2018. - 230 с.

4. Офіційний сайт Міністерства оборони України. Рекомендації з оборонного планування на основі спроможностей. - Режим доступу: https://www.mil.gov.ua/content/other/Recommendationson_CBP_120617.pdf.

5. Теорія озброєння. Науково-технічні проблеми та завдання. Т. 5. Воєнно-технічна політика України: формування, стан та шляхи удосконалення: монографія / І.Б. Чепков, В.В. Зубарєв, В.О. Смірнов та ін. - К.: ВД Дмитра Бураго, 2017. $-448 \mathrm{c}$.

6. Методичний підхід до формування оптимального варіанту програмних заходів з оснащення авіації збройних сил літальними апаратами / О.С. Мавренков, В.В. Логінов, В.В. Войтенко, С.В. Кирнажицький // Наука і техніка Повітряних Сил Збройних Сил України - 2016. - № 1(22). - С. 46-49.

7. Чепков І.Б. Основні аспекти методології формування та супроводження реалізації середньострокових програм озброєння в умовах особливого періоду / І.Б. Чепков, М.І. Луханін, І.В. Борохвостов // Озброєння та військова техніка. 2016. - № 4(2). - С. 3-8.

8. Борохвостов І.В. Визначення критеріїв та методів оцінювання шляхів забезпечення військових формувань озброєнням та військовою технікою / І.В. Борохвостов, М.О. Білокур // Озброєння та військова техніка. - 2018. № 3(19). - С. 3-8.

9. Бадрак В.В. Переозброєння Збройних Сил України: раціоналізація підходів, пошук альтернативних шляхів / В.В. Бадрак // Озброєння та військова техніка. - 2016. - № 1(9). - С. 3-8.

10. Борохвостов В.К. Питання формування ціни на продукцію військового призначення, що накуповується за імпортом / В.К. Борохвостов, О.М. Рябець, М.Б. Сушак // Озброєння та військова техніка. - 2016. - № 3(11) - С. 8-13.

11. Оцінювання спроможностей угруповань військ (сил) за функціональною групою “Застосування” / В.В. Биченков, А.А. Корецький, О.Г. Оксіюк, В.І. Вялкова // Східно-європейський журнал передових технологій. - 2018. - № 3. C. 33-44.

12. Фінансово-економічні аспекти планування розвитку озброєння і військової техніки з урахуванням витрат на забезпечення всього життєвого циклу зразків озброєння і військової техніки / П. Пархоменко, І. Ткач, О. Деменєв, С. Левченко // Social development \& Security. - 2019. - № 6(9). - C. 22-37. - Режим доступу: http://webcache.googleusercontent.com/search?q=cache:RUYPGkIb6Q8J:www.paperssds.eu/index.php/JSPSDS/article/downloa $\mathrm{d} / 157 / 162+\& \mathrm{~cd}=1 \& \mathrm{hl}=\mathrm{ru} \& \mathrm{ct}=\mathrm{clnk} \& \mathrm{gl}=\mathrm{ua}$.

13. Дроздов С.С. Формалізовані критерії раціональності програми розвитку системи озброєння тактичної авіації Повітряних Сил Збройних Сил України на довгостроковій перспективі (прогнозованій) загрозі / С.С. Дроздов, О.Б. Леонтьєв, М.В. Науменко // Збірник наукових праць Харківського національного університету Повітряних Сил. - 2020. № 3(65). - C. 13-24. https://doi.org/10.30748/zhups.2020.65.02.

14. Леонтьєв О.Б. Напрями удосконалення науково-методичного апарату обгрунтування основних напрямів розвитку системи озброєння авіації Повітряних Сил Збройних Сил України / О.Б. Леонтьєв, М.В. Науменко // Наука і техніка Повітряних Сил Збройних Сил України. - 2020. - № 3(40). - С. 69-78. https://doi.org/10.30748/nitps.2020.40.08.

15. Дроздов С.С. Методичний підхід до розв'язування математичної задачі синтезу раціональної програми розвитку системи озброєння тактичної авіації на основі критерію мінімізації фінансових витрат за умови досягнення необхідних бойових спроможностей / С.С. Дроздов, О.Б. Леонтьєв, М.В. Науменко // Наука і техніка Повітряних Сил Збройних Сил України. - 2020. - № 4(41). - С. 54-63. https://doi.org/10.30748/nitps.2020.41.06.

16. Леонтьєв О.Б. Методичний підхід до розв'язування математичної задачі синтезу раціональної програми розвитку системи озброєння тактичної авіації на основі критерію досягнення максимально можливого рівня бойових спроможностей за умови обмеженого ресурсного забезпечення / О.Б. Леонтьєв, М.В. Науменко // Наука і техніка Повітряних Сил Збройних Сил України. - 2021. - № 1(42). - С. 50-60. https://doi.org/10.30748/nitps.2021.42.06.

17. Візія Повітряних Сил 2035. - Вінниця: Командування Повітряних Сил Збройних Сил України, 2020. - 42 с.

18. Науменко М.В. Математична модель темпу серійного виробництва багатоцільових літаків тактичної авіації / М.В. Науменко // Збірник наукових праць Харківського національного університету Повітряних Сил. - 2021. - № 1(67). - C. 47-57. https://doi.org/10.30748/zhups.2021.67.06.

19. Офіційний сайт Міністерства оборони України. Методичні рекомендації з фінансово-економічного обгрунтування вартості повного життєвого циклу спроможностей з урахуванням принципів і стандартів НАТО. - Режим доступу: https://www.mil.gov.ua/content/oboron_plans/metod_recom_z_fin_ekon_life_ciklu_nato.pdf.

20. Теорія озброєння. Науково-технічні проблеми та завдання. Т. 6. Воєнно-технічна політика України: формування, стан та шляхи удосконалення: монографія / І.Б. Чепков, В.В. Зубарєв, В.К. Борохвостов та ін. - К.: ВД Дмитра Бураго, 2018. $-475 \mathrm{c}$.

21. Бегма В.М. Концептуальні засади стратегій інвестиційно-інноваційного розвитку оборонно-промислових комплексів держав. Досвід для України: аналіт. доп. / В.М. Бегма, О.О. Свергунов. - К.: НІСД, 2019. - 64 с.

22. Іванова І.М. Особливості формування вартості продукції оборонного призначення / І. М. Іванова // Стратегічні 
пріоритети. - 2016. - № 2. - С. 82-87. - Режим доступу: http://nbuv.gov.ua/UJRN/spa_2016_2_11.

23. Науково-методичні підходи до аналізу воєнно-технічних та техніко-економічних аспектів життєвого циклу зразків озброєння та військової техніки / І.В. Павловський, І.Б. Чепков, В.К. Борохвостов, І.В. Борохвостов, О.М. Рябець // Наука і оборона. - 2017. - № 2. - С. 43-51.

24. Методика розподілу оборонного бюджету України між складовими сил оборони з урахуванням показників потреб та пріоритетності завдань цих складових на плановий рік / О.М. Семененко, Р.В. Бойко, О.Г. Водчиць, С.П. Василенко, Г.Г. Зубрицька, О.І. Кремешний // Наука і техніка Повітряних Сил Збройних Сил України. - 2017. - № 4(29). C. 123-131. https://doi.org/10.30748/nitps.2017.29.17.

25. Сучасний метод бойових потенціалів в прикладних задачах планування розвитку та застосування тактичної авіації: монографія / Б.Й. Семон, О.Б. Леонтьєв та ін. - К.: НАОУ, 2009. - 336 с.

26. РИА Новости. - Режим доступу: https://ria.ru/20181031/1531825257.html.

27. Najväčší modernizačný projekt ozbrojených síl $\mathrm{v}$ histórii sa stáva realitou, minister obrany podpísal zmluvy $\mathrm{k}$ obstaraniu lietadiel F-16. - Режим доступу: https://www.mod.gov.sk/43306-sk/najvacsi-modernizacny-projekt-ozbrojenych-silv-historii-sa-stava-realitou-minister-obrany-podpisal-zmluvy-k-obstaraniu-lietadiel-f-16.

28. Lockheed Martin Awarded Contract To Build F-16 Block 70 Aircraft For Bahrain. - Режим доступу: https://news.lockheedmartin.com/2018-06-25-Lockheed-Martin-Awarded-Contract-to-Build-F-16-Block-70-Aircraft-forhrain?_ga=2.14981810.509777428.1609405198-1479502474.1609405198.

29. Gulf Countries, US Must Boost 4th \& 5th Fifth Gen Fighter Data Sharing. - Режим доступу: https://breakingdefense.com/2020/12/gulf-countries-us-must-boost-4th-5th-fifth-gen-fighter-data-sharing/.

30. United Arab Emirates - Equipment In Support Of A Direct Commercial Sale Of F-16 Block 61 Aircraft. - Режим доступу: https://www.dsca.mil/press-media/major-arms-sales/united-arab-emirates-equipment-support-direct-commercial-sale-f-16.

31. Contracts For April 2, 2020 Lockheed Martin Aeronautics, Ft. Worth, Texas, has been awarded a \$512,004,418 firmfixed-price contract for F-16 Block 70 production for the Republic of Bulgaria. - Режим доступу: https://www.defense.gov/Newsroom/Contracts/Contract/Article/2135175/\#LOCKHEED040220.

32. Южная Корея закупит еще 40 истребителей F-35. - Режим доступу: https://rg.ru/2020/08/26/iuzhnaia-koreiazakupit-eshche-40-istrebitelej-f-35.html.

33. Бельгия выберет американский F-35, а не европейский истребитель для замены своих самолетов. - Режим доступу: https://www.eurointegration.com.ua/rus/news/2018/10/22/7088477/.

34. Як різні країни оновлюють свої бойові авіапарки. - Режим доступу: https://armyinform.com.ua/2020/11/yak-riznikrayiny-onovlyuyut-svoyi-bojovi-aviaparky/.

35. Сделка на \$4,6 млрд: зачем Польше американские истребители пятого поколения. - Режим доступу: https://www.avia port.ru/digest/2020/01/31/624959.html.

36. Greece Wants F-35s So Quickly It's Willing to Accept Used Aircraft. - Режим доступу: https://www.airforcemag. com/greece-wants-f-35s-so-quickly-its-willing-to-accept-used-aircraft/.

37. Программа закупки Румынией истребителей F-16: состояние и перспективы. - Режим доступу: https://bmpd.livejournal.com/2385586.html.

38. Greece equips itself with the RAFALE in the continuity of a partnership with DASSAULT AVIATION of more than 45 years. - Режим доступу: https://www.dassault-aviation.com/en/group/press/press-kits/greece-equips-itself-with-the-rafale-inthe-continuity-of-a-partnership-with-dassault-aviation-of-more-than-45-years/.

39. Senate to vote on banning $\$ 23$ billion UAE arms sales next week. - Режим доступу: https://www.defensenews.com/congress/2020/12/03/us-senate-to-vote-next-week-on-23b-uae-arms-sale/?utm_source= Sailthru\&utm_medium=email\&utm_campaign= EBB\%2012.04.20\&utm_term=Editorial\%20-\%20Early\%20Bird\%20Brief.

40. Стоимость авиационной техники. - Режим доступу: http://www.airbase.ru/alpha/rus/ts/price/.

41. World Bank national accounts data Inflation, GDP deflator (annual \%). - Режим доступу: https://data.worldbank.org/indicator/NY.GDP.DEFL.KD.ZG.

42. Демидов Б.А. Теория и методы военно-научных исследований вооружения и военной техники / Б.А. Демидов. Харьков: ВИРТА, 1990. - 558 с.

43. Івахненко А.Г. Индуктивный метод самоорганизации моделей сложных систем / А.Г. Івахненко. - К.: Наук. думка, 1981. $-296 \mathrm{c}$.

44. Хетагуров Я.А. О построении аппроксимирующих функций характеристик малого числа систем / Я.О. Хетагуров. - Режим доступу: https://www.ispras.ru/proceedings/docs/2012/22/isp_22_2012_475.pdf.

45. Елисеева И.И. Эконометрика / И.И. Елисеева. - М.: Финансы и статистика, 2003. - 344 с.

46. Каморников С.Ф. Эконометрика / С.Ф. Каморников, С.С. Каморников. - М.: Интеграция, 2012. - 262 с.

47. Ивахненко А.Г. Моделирование сложных систем по эксперементальным данным / А.Г. Ивахненко, Ю.П. Юрачковский. - М.: Радио и связь, 1987. - 120 с.

48. Средние зарплаты в Германии - по профессиям, сферам, группам и регионам. - Режим доступу: https://www.tupa-germania.ru/rabota/srednjaja-zarplata-v-germanii.html\#dejat.

49. Зарплаты. - Режим доступу: https://migrantvisa.ru/zarplata/.

50. Зарплаты в России. - Режим доступу: https://www.tadviser.ru/index.php/\%D0\%A1\%D1\%82\%D0\% B0\%D1\%82\%D1\%8C\%D1\%8F:\%D0\%97\%D0\%B0\%D1\%80\%D0\%BF\%D0\%BB\%D0\%B0\%D1\%82\%D1\%8B_\%D0\%B2_\% D0\%A0\%D0\%BE\%D1\%81\%D1\%81\%D0\%B8\%D0\%B8.

51. Средняя часовая заработная плата. - Режим доступу: https://economic-definition.com/Employment /Srednyaya_chasovaya_zarabotnaya_plata_Average_hourly_wages_eto.html. 


\section{Відомості про автора:}

\section{Науменко Марина Володимирівна}

кандидат технічних наук старший науковий співробітник докторант

Харківського національного університету

Повітряних Сил ім. І. Кожедуба,

Харків, Україна

https://orcid.org/0000-0002-1216-9263

\section{Information about the author:}

\section{Maryna Naumenko}

Candidate of Technical Sciences Senior Research

Doctoral Student

of Ivan Kozhedub Kharkiv

National Air Force University,

Kharkiv, Ukraine

https://orcid.org/0000-0002-1216-9263

\title{
УСОВЕРШЕНСТВОВАННАЯ МАТЕМАТИЧЕСКАЯ МОДЕЛЬ СТОИМОСТИ МНОГОЦЕЛЕВЫХ ТАКТИЧЕСКИХ ИСТРЕБИТЕЛЕЙ
}

\author{
М.В. Науменко
}

Представлена усовершенствованная математическая модель стоимости многоиелевых тактических истребителей, которая в отличие от существующей, построена на выборке, включающей информацию о самых современных типах многоцелевых тактических истребителей, реализованных в мировой практике военного авиастроения, и более адекватно отражает зависимость цены серийных изделий на мировом рынке вооружений от обобщенных показателей их качества. Показателями качества в факторном пространстве математической модели приняты коэффициенты боевых потенциалов многоцелевых тактических самолетов при выполнении ими задач уничтожения противника в воздухе и задач поражения наземных иелей, определенных в эталоне более современного многоцелевого истребителя типа F-16Е. Построенная математическая модель, для исключения влияния факторов инфляиии позволяет определить цену на приобретение серийных самолетов на мировом рынке вооружений по курсу доллара США 2014 финансового года.

Ключевые слова: планирование на основе возможностей, критерии рациональности, научно-методический аппарат, оптимизация, рациональная программа развития, система вооружения авиации Воздушных Сил Вооруженных Сил Украинье.

\section{ADVANCED MATHEMATICAL COST MODEL OF MULTI-ROLE TACTICAL FIGHTERS}

\section{Naumenko}

The cost indicators of multi-role fighters, together with the pace of their production, largely determine the development trends of the global arms market, which in turn puts forward for potential buyers of combat aircraft certain restrictions on the possibility of purchasing it. The availability of adequate methodological support for estimating the cost of serial tactical fighters will allow to obtain estimates of the cost of modern and promising combat aircraft, which is presented (planned to be presented) on the world arms market. In addition, the correct assessment of the cost of serial multi-purpose tactical aircraft, which can be considered as an alternative to procurement, is the basis for planning the State budget expenditures in the medium and long term, which should be directed to the Security and Defense Sector. This information will determine the financial component of the system of restrictions of formalized criteria for assessing the rationality of programs for the development of weapons and military equipment of tactical aviation of the Air Force of the Armed Forces of Ukraine. The article presents an improved mathematical model of the cost of multi-role tactical fighters, which, in contrast to the existing one, more adequately reflects the dependence of the price of modern and promising multi-role fighters on the world arms market on generalized indicators of their quality. Such indicators are the coefficients of combat potential of multi-purpose tactical aircraft in the performance of their tasks of destroying the enemy in the air and the task of destroying ground targets. The correctness of the calculations of the forecast values of the cost of serial combat aircraft was ensured by adjusting the calculations of the coefficients of combat potential from the standard model F-4B to a more modern multi-role fighter F-16E. Based on the results of assessing the adequacy and accuracy of the developed advanced mathematical model of the cost of serial multi-purpose tactical aircraft, it can be concluded that its practical use is justified during the substantiation of proposals for the synthesis of rational programs and plans for tactical aviation of the Air Force of Ukraine armaments in the sector of combat aircraft.

Keywords: capability-based planning, rationality criteria, scientific and methodological apparatus, optimization, rational development program, System of the Air Force of the Armed Forces of Ukraine. 